DOI: $10.22363 / 2312-9220-2021-26-4-664-671$

УДК 316.77

\title{
Deep Mediatization: Rethinking a Figurational Approach
}

\author{
Evgeniya G. Nim \\ National Research University Higher School of Economics, \\ 20 Myasnitskaya St, Moscow, 101000, Russian Federation \\ $\bowtie$ nimeg@mail.ru
}

\begin{abstract}
The article analyzes the possibilities and limitations of the figurative approach to the deep mediatization study, developed by Andreas Hepp and Nick Couldrie. To what extent is figurative theoretical optics sensitive to the processes of social worlds and practices transformation under the media influence? What are the possible directions of revision and further development of this approach? The figurative approach to deep mediatization is a powerful theoretical tool to explore this complex, non-linear meta-process. Focusing on figurations helps to avoid media centrism and emphasize the social life procedurality. At the same time, the figurations concept (understood as collectives, organizations, and institutions) raises some questions. In particular, the thesis about special media ensembles inherent in different figurations does not always work. This is due to the emergence of multifunctional platforms that can become a single digital infrastructure for many figurations. Such platforms have the potential of the ecosystem for a mediatized social life. Further analysis of the relationship between figurations and platforms is required, which does not reduce platforms only to the technological component of figurations. Bridging the deep divide between human actors and technology would also lead to new readings of medialogics (such as human-machine logics).
\end{abstract}

Keywords: digital media, deep mediatization, figurational approach, platforms, media logics

Conflicts of interest. The author declares that there is no conflict of interest.

Article history: submitted: March 16, 2021; accepted: June 11, 2021.

For citation: Nim, E.G. (2021). Deep mediatization: rethinking a figurational approach. RUDN Journal of Studies in Literature and Journalism, 26(4), 664-671. doi: 10.22363/23129220-2021-26-4-664-671 


\title{
Глубокая медиатизация: пересматривая фигуративный подход
}

\author{
Е.Г. Ним \\ Национальный исследовательский университет «Высшая школа экономики», \\ Российская Федераџия, 101000, Москва, ул. Мяснищкая, 20 \\ $\bowtie$ nimeg@mail.ru
}

\begin{abstract}
Аннотация. В статье анализируются возможности и ограничения фигуративного подхода к изучению глубокой медиатизации, развиваемого Андреасом Хеппом и Ником Коулдри. В какой мере фигуративная теоретическая оптика чувствительна к процессам трансформации социальных миров и практик под влиянием медиа? В каких направлениях возможна ревизия и дальнейшее развитие этого подхода? Фигуративный подход к глубокой медиатизации является сильным теоретическим инструментом, позволяющим исследовать этот комплексный, нелинейной метапроцесс. Фокус на фигурациях помогает избежать медиацентризма и акцентировать процессуальность социальной жизни. В то же время концепт фигураций (понимаемых как коллективы, организации и институты) вызывает некоторые вопросы. В частности, тезис об особых медиаансамблях, присущих разным фигурациям, не всегда работает. Это связано с появлением многофункциональных платформ, способных стать единой цифровой инфраструктурой для множества фигураций. Подобные платформы имеют потенциал экосистем для медиатизированной социальной жизни. Необходим дальнейший анализ связи фигураций и платформ, не редуцирующий платформы только к технологической составляющей фигураций. Устранение глубокого разрыва между людьми-акторами и технологиями также привело бы к новым прочтениям медиалогики.
\end{abstract}

Ключевые слова: цифровые медиа, глубокая медиатизация, фигуративный подход, платформы, медиалогика

Заявление о конфликте интересов. Автор заявляет об отсутствии конфликта интересов.

История статьи: поступила в редакцию - 6 марта 2021 г.; принята к публикации - 11 июня 2021 г.

Для цитирования: Nim E.G. Deep mediatization: rethinking a figurational approach // Вестник Российского университета дружбы народов. Серия: Литературоведение. Журналистика. 2021. Т. 26. № 4. С. 664-671. doi: 10.22363/2312-9220-2021-26-4-664-671

\section{Introduction}

Over the past ten years, the concept of mediatization has gained widespread recognition among academics. The concept of mediatization is not just a new concept reflecting the ever-increasing influence of media on different sectors of society and culture - theorists of mediatization claim to be a "paradigmatic shift" in media studies [6. P. 315] and social science in general. In the discourse 
on mediatization, three perspectives can be distinguished, which, for all their differences, are not mutually exclusive and hermetic: institutionalist, socialconstructivist, and material [10]. This typology is based on different ways of conceptualizing media — as a social institution, symbolic form, and material technology. This article focuses on the figurative approach to deep mediatization developed by Nick Couldry and Andreas Hepp within the social-constructivist (cultural) tradition.

According to these authors, the concept of deep mediatization reflects a fundamentally new quality of the media environment and the social world saturated with media technologies [3. P. 5]. In their view, mediatization is a long process spanning six centuries of human culture. Couldry and Hepp distinguish four "waves" in it, each of which has a specific technological principle: mechanization, electrification, digitalization, and datafication [3. P. 38-52]. Deep mediatization begins with the development of computers, machine intelligence, the Internet, and mobile communications. It is the situation when media technologies are penetrating all spheres of personal and social life, transforming the practices of individuals, communities, organizations, and social institutions. Deep mediatization is marked by five distinctive trends: the differentiation of digital media, their connectivity, media's omnipresence, the accelerating pace of media innovation, and the rise of datafication [5. P. 40].

Mediatization and deep mediatization are considered as "sensitizing concepts" [5. P.4], allowing a better understanding of the transformations of various areas of social and cultural life associated with a change in the media environment. However, this sensitivity largely depends on the theoretical perspective within which specific manifestations of mediatization are described and explained. In this article, the author uses the figurative approach of Couldry and Hepp, which seems to be the most flexible, comprehensive, and relevant for the study of the mediatized social world. To what extent is this approach sensitive to deep mediatization processes? What are the limitations of figurative perspective and the possibilities for its further modification? Without claiming to be a fullfledged revision of figurative optics, the author outlines some of its possible directions.

\section{A figurational approach}

The cultural version of mediatization theory presented by Nick Couldry and Andreas Hepp distances itself from media centrism. For them, the starting point of analysis is, first of all, "not media themselves, but the social domains and, in a second step, the role of media in a domains' construction" [5. P. 100]. Their approach to the study of deep mediatization, described in the book "The Mediated Construction of Reality" (2016), is formed at the intersection of social theory and media studies.

Couldry and Hepp suggested their version of figurative sociology that is relevant to our digital age. The figuration concept of the German sociologist 
Norbert Elias [4], adapted by them, makes it possible to consider such "social bodies" as collectives, organizations, social institutions, and even entire societies procedurally, as existing only in the interaction of people. Unlike other procedural concepts - in particular, "networks", which reduce the social world to a multitude of constellations of interconnected actors [2] or "assemblage", which compose aggregates from human and non-human actants [9] into a "flat landscape" - the figuration concept has certain heuristic advantages, according to Couldry and Hepp. It contains both possibilities: to see structures in the flow of social life as patterns of interdependences and to understand the place of material technologies in heterogeneous networks.

Any figuration presupposes the presence of the three elements: (1) a specific constellation of interrelated social actors; (2) "dominating frames of relevance" that determine constitutive practices and the nature of figuration; (3) communicative practices (based on a specific "media ensemble") intertwined with other social practices inherent in this figuration [5. P. 104-105].

Media and the "ensembles" they form are the technological basis for communication in figurations, without which the latter can no longer exist.

While recognizing the overall productivity of the figurative approach in studies of deep mediatization, it should be noted that it has its limitations and opportunities for further development, discussed below.

\section{Figurations vs. platforms}

First, the introduction of the communicative figurations concept does not bring fundamental novelty to the understanding and description of the mediatization of social life from the standpoint of the cultural approach. This is a kind of "rebranding" of the former concept of "mediatized worlds" [7], which goes back to the "life" / "social" / "small" worlds of phenomenology, which are now experiencing a noticeable influence of media technologies. That is, the "patterns" for "cutting out" social reality have remained largely the same (e.g.: the family, or state). These are "classical" social worlds (spheres, fields, locales), only viewed through the prism of ubiquitous media. The figuration concept overcomes the undesirable dualism of actor and structure, and is free from the connotations of hermeticity, territoriality, and substantiality inherent in "worlds", but it is more important for the development of social theory, and to a lesser extent - for understanding the mediatization processes. Are Couldry and Hepp exploring the mediatization of social life with inspiration from Elias, or are they developing Elias's figurative sociology while adapting it to digital realities? Is it worth it to come up with new sociology to study the impact of media technologies in different sectors of society and culture? Definitely worth it, although the rapid processes of deep mediatization will require more radical theoretical optics.

The figurative approach proceeds from the fact that it is not the media that build specific eras or worlds around themselves, but social worlds (figurations) have their media ensemble, which changes over time. However, in the conditions 
of digitalization and datafication, "infrastructural platforms" [5. P. 27], created by large technology companies (Alphabet, Amazon, Apple, etc.), are of particular importance. Social life is "moving" to platforms, and not only to the such as Facebook, Airbnb, or Uber, which offer a rather narrow range of possible actions. In several countries, there is a trend towards the creation of multifunctional superapps like the Chinese WeChat, where the user can satisfy many needs - from news, shopping, and payments to medical control, dating, and entertainment - in one "place". In Indonesia, the equivalent of WeChat is Gojek, in Malaysia Grab, in Latin America - Rappi, in Russia - Sberbank, Yandex.Go, VKontakte and Tinkoff.

WeChat is somewhat close to the imaginary platform "The Circle" from Dave Eggers' 2013 dystopian novel of the same name, which was referred to by Couldry and Hepp in their book "The Mediated Construction of Reality" (2016). In this novel, not having an account in "The Circle" or not using it meant losing access to the digitalized social world. The WeChat demonstrates that the thesis about special media ensembles inherent in different figurations, and media repertoires, individual for each actor, may no longer work: most Chinese people use this super-app in all situations and "worlds".

The described trends indicate that soon such mega-platforms can become an ecosystem of mediatized social worlds-figurations. It is still difficult to say what consequences the concentration of social life on one or several global infrastructural platforms may have, but this will likely require a transition from "figurative" to "platform" sociology. In any case, a clearer relationship between figurations and platforms will be required, in which platforms will be seen as more (or other) than just the technological basis of figurations.

\section{Platforms logics, human-machine logics}

Media logics is one of the key concepts in mediatization research, which both Hepp and Couldry have taken very critically. Further, the productive reinterpretations of media logics are possible, but this requires a modification of the figurative approach itself.

In his book "Deep Mediatization" (2020), Hepp systematizes different interpretations of media logics, highlighting three approaches, which are based on interaction, organization, or technology. In the first case, it is an approach to media logics as forms of interaction, assuming that each medium has its way of encoding and decoding content. These are certain formats, genres, aesthetics, and language that determine the specificity of media representations of social phenomena and processes [1]. In studies of mediatization, media forms are usually studied not by themselves, but in the context of their socio-cultural influence. The second, the organization approach, is characteristic of the so-called strong version of the mediatization theory [8] and describes how non-media actors and institutions adapt to the rules of media organizations. The third, technological 
perspective, focuses on the materiality of media technologies, in particular through the concept of affordances, prompting certain patterns of media use [11].

Hepp believes that currently, none of these interpretations of media logics can be a useful metaphor for describing the essence of deep mediatization processes. The main critical argument is that, in all three cases, "media become a 'static object' that is powerful in itself" [5. P. 67]. This attributable power of the media lies in their perceived ability to structure human practices in a particular way. This view overlooks the importance of actors' perception, use, and transformation of technology ignores the dynamics of the media. If technologies have "structuring" power, then it is delegated to them by people who produce, consume, and constantly rethink/remake these technologies. According to Hepp, it is more appropriate to speak of the "molding forces" [5. P. 57] of media, which manifest themselves in the institutionalization and materialization of social practices.

Given this criticism, it seems problematic to define media logics as the logic of platformization of social life, which would be the fourth way of conceptualizing it based on infrastructural platforms. Yet, this approach has the potential if we understand the platforms not only as limited in functionality services (like Facebook or Airbnb), but as global digital ecosystems comparable to the fictional "Sphere" or the real, but not so comprehensive WeChat.

However, further here will be analyzed not this promising thesis, but a more radical argument in favor of interpreting media logics as human-machine logics.

The fact that the media should be seen as a process does not raise objections. The main difficulty for rethinking media logics within the framework of the figurative approach is different. It is connected with the fact that the media and people are separated as different components of figurations. Couldry and Hepp introduce technology into the structure of figurations but consider only people as actors. Therefore, although the media can appear in the role of the social world modifiers, their "molding forces" are constructed as factors external to people. In this perspective, the media themselves do not possess agency (like Latur's nonhuman actants).

Media technologies here are still something that can be turned off at will, put aside, or left (like a mobile phone or a social network), remaining "yourself". Although currently such "disconnections" from the media are easy, nevertheless, there is an increasingly noticeable mediatization of the human actor and his "growing' into digital infrastructures. Media is becoming more mobile, smart, immersive, and invasive. As the human body is equipped with sensors and a smart digital environment develops, into which such mediatized bodies will be integrated along with other smart objects, ideas about corporeality, identity, and humanity as well as media and media logics — will begin to change significantly.

Incorporated at the cognitive and physical levels, media logics is likely to structure differently both the perception of the social world and social practices. Of course, an attempt to conceptualize media logics as "human-machine logics" looks like a difficult task, but the theory of mediatization "waves" has good 
predictive potential. In addition, some of the described tendencies are already present, and if such a categorical separation of human actors and technologies is somehow overcome, the metaphor of media logics can get a "second wind".

\section{Conclusion}

The figurative approach to deep mediatization remains a powerful theoretical tool for exploring this complex, non-linear meta-process. At the same time, the approach is more significant as a social theory articulating the role of media technologies in social world construction. Focusing on figurations as mediatized worlds avoid media centrism, but this does not provide much for understanding the very process of deep mediatization. The "binding" to figurations encourages the mediatization study through "social domains" (collectives, organizations, social institutions, states), which have their specific practices and media ensembles that support them. However, as shown by the example of WeChat, the media ensemble thesis does not always work: multifunctional platforms can become the digital infrastructure for the social world and themselves become this world, "figurations of figurations". A deep analysis of the relationship between figurations and platforms is needed, which does not reduce platforms only to the technological component of figurations. Perhaps the result of such an analysis will be a new reading of media logics as the logic of social life platformization. A more radical interpretation of media logics as human-machine logics involves overcoming the dualism of people/actors and technologies/platforms, embedded in the figurations model.

As Andreas Hepp notes, the future as a whole is not predetermined, and even more so, not predetermined by technologies [5. P. 177-178]. However, for mediatization to remain a "sensitizing concept" within the figurative approach framework, it should become even more visionary, to which the model of "mediatization waves", which has a high predictive potential.

\section{References}

[1] Altheide, D.L., \& Snow, R.P. (1979). Media Logic. Beverly Hills, CA: Sage.

[2] Castells, M. (2009). Communication Power. Oxford: Oxford University Press.

[3] Couldry, N., \& Hepp, A. (2016). The Mediated Construction of Reality. Cambridge, UK; Malden, MA: Polity Press.

[4] Elias, N. (1978). What Is Sociology? New York: Columbia University Press.

[5] Hepp, A. (2020). Deep mediatization. London and New York: Routledge.

[6] Hepp, A., Hjarvard, S., \& Lundby, K. (2015). Mediatization: Theorizing the Interplay between Media, Culture and Society. Media, Culture \& Society, 37(2), 314-324. doi: 10.1177/0163443715573835

[7] Hepp, A., \& Krotz, F. (2014). (Eds.) Mediatized Worlds. Culture and Society in a Media Age. Basingtoke: Palgrave Macmillan.

[8] Hjarvard, S. (2013). The Mediatization of Culture and Society. London: Routledge.

[9] Latour B. (2005). Reassembling the Social. Oxford: Oxford University Press. 
[10] Lundby, K. (2014). Mediatization of Communication. In K. Lundby (Ed.) Mediatization of Communication (pp. 3-35). Berlin: De Gruyter Mouton.

[11] Nagy, P., \& Neff, G. (2015). Imagined Affordance: Reconstructing a Keyword for Communication Theory. Social Media + Society, 1(2), 1-9. doi: 10.1177/20563051 15603385

\section{Bio note:}

Evgeniya G. Nim, Candidate of Sociological Sciences, Associate Professor, School of Media, National Research University Higher School of Economics. ORCID: 0000-00017349-9429; e-mail: nimeg@mail.ru

\section{Сведения об авторе:}

Ним Евгения Генриевна, кандидат социологических наук, доцент департамента медиа Национального исследовательского университета «Высшая школа экономики». ORCID: 0000-0001-7349-9429; e-mail: nimeg@mail.ru 